\title{
Role of Angiotensin II in Dietary Modulation of Rat Late Distal Tubule Bicarbonate Flux In Vivo
}

\author{
David Z. Levine, Michelle lacovitti, Susan Buckman, and Kevin D. Burns \\ Department of Medicine, University of Ottawa, and Ottawa General Hospital, Ottawa, Ontario, Canada K1H 8M5
}

\begin{abstract}
We have reported that overnight fasting stimulates bicarbonate reabsorption $\left(\mathrm{J}_{\mathrm{tCO} 2}\right)$ in rat distal tubules. The present in vivo microperfusion studies evaluated the hypothesis that endogenous angiotensin II (AII) mediates this response. Rat late distal (LD) tubules were perfused at $8 \mathrm{nl} / \mathrm{min}$ in vivo with a hypotonic solution containing $28 \mathrm{mM}$ bicarbonate. In overnight-fasted rats, $\mathrm{LD} \mathrm{J}_{\mathrm{tCO} 2}$ was significantly higher than in normally fed rats $(50 \pm 4$ vs. $16 \pm 6 \mathrm{pmol} / \mathrm{min} \cdot \mathrm{mm}, P<$ $0.05)$. When overnight-fasted rats were salt-loaded, $\mathrm{J}_{\mathrm{tCO} 2}$ fell significantly $(38 \pm 3 \mathrm{pmol} / \mathrm{min} \cdot \mathrm{mm}, P<0.05)$. Conversely, in fed rats ingesting a zero-salt diet, $\mathrm{J}_{\mathrm{tCO} 2}$ increased threefold $(45 \pm 5 \mathrm{pmol} / \mathrm{min} \cdot \mathrm{mm}, P<0.05)$. Enalaprilat infusion $(0.25 \mu \mathrm{g} / \mathrm{kg}$ body wt, intravenously), in these zero-salt and overnight-fasted rats, reduced $\mathrm{LD} \mathrm{J}_{\mathrm{tCO} 2}$ values to normal. Further, infusion of losartan $(5 \mathrm{mg} / \mathrm{kg}$ body wt, intravenously), the specific AII $\mathrm{AT}_{1}$ receptor blocker, reduced $\mathrm{J}_{\mathrm{tCO} 2}$ in overnight-fasted rats by two-thirds $(16 \pm 4 \mathrm{pmol} / \mathrm{min} \cdot \mathrm{mm}$, $P<0.05)$. Finally, we perfused $10^{-11} \mathrm{M}$ AII intraluminally with and without $10^{-6} \mathrm{M}$ losartan: AII increased $\mathrm{J}_{\mathrm{tCO} 2}$ to $45 \pm 6 \mathrm{pmol} / \mathrm{min} \cdot \mathrm{mm}$, equal to the zero-salt flux. This was completely abrogated by simultaneous losartan perfusion. Therefore, these results suggest that AII is an in vivo stimulator of late distal tubule bicarbonate reabsorption. (J. Clin. Invest. 1996. 97:120-125.) Key words: bicarbonate reabsorption • fasting • angiotensin II • losartan • late distal tubule
\end{abstract}

\section{Introduction}

Using in vivo microperfusion techniques in the rat, we have shown that distal tubule net bicarbonate reabsorption $\left(\mathrm{J}_{\mathrm{tCO} 2}\right),{ }^{1}$ which is modest or absent in normally fed rats, is greatly en-

Abstracts referring to portions of this work have been presented at the 1994 meeting of the Royal College of Physicians and Surgeons of Canada, and at the 1994 meeting of the American Society of Nephrology.

Address correspondence to David Z. Levine, M.D., Department of Medicine, Health Sciences Building, 451 Smyth Road, Room 1333, Ottawa, Ontario, Canada K1H 8M5. Phone: 613-737-8145; FAX: 613737-8141.

Received for publication 10 July 1995 and accepted in revised form 28 September 1995.

1. Abbreviations used in this paper: AII, angiotensin II; ACE, angiotensin-converting enzyme; $\mathrm{BW}$, body weight; $\mathrm{J}_{\mathrm{Cl}}$, chloride flux; $\mathrm{J}_{\mathrm{tCO} 2}$, total $\mathrm{CO}_{2}$ reabsorption $\left(\mathrm{tCO}_{2}\right.$ reabsorption and bicarbonate reabsorption are used interchangeably); $\mathrm{J}_{\mathrm{v}}$, water reabsorption; $\mathrm{LD}$, late distal; PRA, plasma renin activity.

J. Clin. Invest.

(C) The American Society for Clinical Investigation, Inc.

0021-9738/96/01/0120/06 \$2.00

Volume 97, January 1996, 120-125 hanced by overnight fasting (1). Recently, we demonstrated that in fed rats systemic angiotensin II (AII) infusion briskly augments distal tubule $\mathrm{J}_{\mathrm{tCO} 2}(2)$. Accordingly, we wondered whether it was possible that endogenous levels of AII might modulate late distal (LD) tubule $\mathrm{J}_{\mathrm{tCO} 2}$ in vivo. The hypothesis that changes in AII might underlie our findings is further strengthened by the observations that our overnight-fasted rats have significant weight loss, excrete little urinary sodium, and drink excessively: AII is a powerful dipsogen, and fasting and/or weight loss as well as sodium deprivation can elicit high plasma levels of AII (3). If it is true that AII underlies the different distal tubule response in fed and fasted rats, it would follow that changes in dietary sodium, angiotensin-converting enzyme (ACE) inhibition, or AII receptor blockade should also influence $\mathrm{LD} \mathrm{J} \mathrm{J}_{\mathrm{tCO} 2}$.

Accordingly, the objective of this study was to test the hypothesis that AII importantly modulates rat $\mathrm{LD} \mathrm{J}_{\mathrm{tCO}}$. The LD tubule, made up of the connecting segment and the initial collecting tubule, and containing both $\mathrm{A}$ and $\mathrm{B}$ type intercalated cells (demonstrable in surface distal tubules available for microperfusion [4]), presumably reflects collecting duct transport, and investigations in this segment should therefore provide insight into regulation of final urine acidification.

Our results support the hypothesis that AII acts as an endocrine or paracrine hormone to modulate LD $\mathrm{J}_{\mathrm{tCO} 2}$. First, LD $\mathrm{J}_{\mathrm{tCO} 2}$ rises briskly in response to ingestion of a zero-salt diet, associated with high plasma renin activity (PRA). Second, this response in zero-salt rats can be inhibited by enalaprilat. Third, in overnight-fasted rats $\mathrm{LD} \mathrm{J}_{\mathrm{tCO} 2}$ augmentation is decreased by drinking saline, enalaprilat infusion, and infusion of the specific $\mathrm{AT}_{1}$ receptor inhibitor losartan. Finally, intraluminal perfusion of AII at a concentration of $10^{-11} \mathrm{M}$ briskly augments $\mathrm{J}_{\mathrm{tCO} 2}$ at the LD site, an effect which is completely abrogated by simultaneous losartan perfusion.

\section{Methods}

Rats and diets. Adult male Sprague-Dawley rats, born and raised in a climate-controlled facility at the University of Ottawa and weighing between 250 and 350 grams, were used in all experiments. They were maintained on standard laboratory rat chow (Ralston-Purina, Woodstock, Ontario, Canada) and tap-water drink before experimentation. They were then separated into four groups and fed the following diets: group 1 (FED), rat chow and tap water; group 2 (FED/NO SALT), zero-NaCl synthetic diet ${ }^{2}$ and distilled water for $3 \mathrm{~d}$; group 3 (FASTED), fasted overnight and distilled water drink; and group 4

2. Zero- $\mathrm{NaCl}$ diet made with (in grams per kilogram of diet): 1.74 $\mathrm{K}_{2} \mathrm{CO}_{3}, 1.81 \mathrm{~K}_{2} \mathrm{SO}_{4}, 1.594 \mathrm{MgCO}_{3} \cdot \mathrm{Mg}(\mathrm{OH})_{2} \cdot 5 \mathrm{H}_{2} \mathrm{O}, 994.86$ basal electrolyte-free diet (Teklad, Madison, WI), and contains $0 \mathrm{mmol} \mathrm{Na} / \mathrm{kg}$ diet, $0 \mathrm{mmol} \mathrm{Cl} / \mathrm{kg}$ diet, and $45.95 \mathrm{mmol} \mathrm{K} / \mathrm{kg}$ diet.

3. High- $\mathrm{NaCl}$ diet made with (in grams per kilogram of diet): 1.15 $\mathrm{Na}_{2} \mathrm{CO}_{3}, 1.74 \mathrm{~K}_{2} \mathrm{CO}_{3}, 1.81 \mathrm{~K}_{2} \mathrm{SO}_{4}, 1.594 \mathrm{MgCO}_{3} \cdot \mathrm{Mg}(\mathrm{OH})_{2} \cdot 5 \mathrm{H}_{2} \mathrm{O}, 28.0$ $\mathrm{NaCl}, 965.71$ basal electrolyte-free diet, and contains $500.82 \mathrm{mmol}$ $\mathrm{Na} / \mathrm{kg}$ diet, $479.12 \mathrm{mmol} \mathrm{Cl} / \mathrm{kg}$ diet, and $45.95 \mathrm{mmol} \mathrm{K} / \mathrm{kg}$ diet. 
(FASTED + SALT), high-NaCl synthetic diet ${ }^{3}$ and distilled water for $2 \mathrm{~d}$, then fasted overnight while drinking $0.9 \%$ saline.

Rats were housed in individual stainless steel metabolic cages for $16 \mathrm{~h}$ (overnight) before microperfusion, allowing measurement of ingested food and drink, and collection of urine under oil, using thymol as a preservative.

Microperfusion experiments. Rats were anesthetized with 100 $\mathrm{mg} / \mathrm{kg}$ Inactin (BYK Gulden, Konstanz, Germany) and prepared for micropuncture as described previously (2). Briefly, the animal was placed on a heated operating table and a tracheostomy was performed, using PE-240 tubing. The left carotid artery was cannulated for continuous blood pressure measurement and collection of blood for electrolyte analyses, while the left jugular vein was cannulated with three lines for infusion of fluid, anesthetic (Somnotol) and 10\% lissamine green. The left kidney was exposed by flank incision, carefully dissected from the adrenal gland, and immobilized in a stainless steel cup covered with mineral oil, while the left ureter was catheterized with PE-50 tubing to ensure proper urine flow.

Rats were infused via the jugular vein with donor plasma from a similarly treated rat at a rate of $1 \%$ body $\mathrm{wt} / \mathrm{h}(\mathrm{BW} / \mathrm{h})$ for $30 \mathrm{~min}$ to replace surgical fluid losses, then infused with $0.9 \%$ saline at $1 \% \mathrm{BW} / \mathrm{h}$ for the remainder of the experiment. The effect of inhibitors of AII on $\mathrm{LD} \mathrm{J}_{\mathrm{tCO} 2}$ was tested by infusing the ACE inhibitor enalaprilat (kindly supplied by Dr. Ernest Prégent) and the specific $\mathrm{AT}_{1}$ receptor inhibitor losartan (a generous donation from Dr. Ronald Smith), in rats from groups 2 and 3. These drugs were infused in solution at $1 \%$ $\mathrm{BW} / \mathrm{h}$ for $5 \mathrm{~min}$ immediately before the experimental period, yielding doses of $0.25 \mu \mathrm{g} / \mathrm{kg} \mathrm{BW}$ and $5 \mathrm{mg} / \mathrm{kg} \mathrm{BW}$, for enalaprilat and losartan, respectively. Samples were taken within 20-60 min of these infusions.

Perfusable LD tubules were identified by injecting a bolus of $1 \%$ lissamine green into surface proximal loops and timing the appearance of two- or three-loop surface distals. LD tubules were identified based on a comparison of the whole kidney transit time and the individual tubular transit time. In many tubules this designation could be confirmed by the appearance of a distal branch in the latex cast, within $1 \mathrm{~mm}$ of the collection site. Tubules were perfused at $8 \mathrm{nl} / \mathrm{min}$ with a hypotonic perfusion solution containing (mM): $28 \mathrm{HCO}_{3}, 26$ $\mathrm{Cl}, 56 \mathrm{Na}, 2 \mathrm{~K}, 22$ urea, and 4 gluconate. When the effect of luminal perfusion of AII was studied, a modified perfusate (1a) containing $\mathrm{CaCl}_{2}$ and $1 \%$ albumin was used (Table I). Calibration of the perfusion pump was done in vitro. Collections of LD samples were quantitative and timed. Samples were accepted after comparing the calcu-

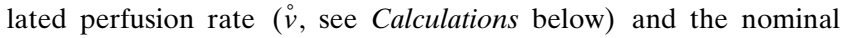
perfusion rate (i.e., at what rate the calibrated perfusion pump was set), and those not within $\pm 15 \%$ of the nominal rate were discarded. Collections were analyzed for inulin, total carbon dioxide $\left(\mathrm{tCO}_{2}\right)$, and chloride concentrations.

Analyses. PRA was measured in rats identically treated to rats from groups 1-4. Blood was collected on ice via the carotid artery in anesthetized rats and centrifuged, and the plasma was stored at

\section{Table I. Perfusion Solutions}

\begin{tabular}{lcc}
\hline & 1 & $1 \mathrm{a}$ \\
\hline $\mathrm{HCO}_{3}(\mathrm{mM})$ & 28 & 28 \\
$\mathrm{Cl}(\mathrm{mM})$ & 26 & 26 \\
$\mathrm{Na}(\mathrm{mM})$ & 56 & 56 \\
$\mathrm{~K}(\mathrm{mM})$ & 2 & 2 \\
Urea $(\mathrm{mM})$ & 22 & 16.6 \\
Gluconate $(\mathrm{mM})$ & 4 & 7.6 \\
Calcium (mM) & - & 1.8 \\
Albumin (\%) & - & 0.1 \\
Osmolality (mosmol/liter) & $131 \pm 1$ & $132 \pm 1$ \\
\hline
\end{tabular}

$-20^{\circ} \mathrm{C}$ until the assay was performed. Using a commercially available clinical assay kit (Incstar Corp., Stillwater, MN), PRA was determined by radioimmunoassay of generated angiotensin I produced during incubation of plasma samples.

Perfusate and sample $\mathrm{tCO}_{2}$ concentrations were measured by microcalorimetry as described previously (2). Micropuncture and sample handling pipettes contained Hepes-buffered mineral oil, and the samples were placed on a quartz dish flooded with Hepes-buffered mineral oil. A separate tray contained four standards (10, 20, 30, and $40 \mathrm{mM} \mathrm{NaHCO}$ ) in water-equilibrated mineral oil. A standard curve was run before sample analysis, and standards bracketed the determination of sample and perfusate $\mathrm{tCO}_{2}$ concentration.

Sample and perfusate chloride concentrations were determined by constant current electrotitration with potentiometric end-point sensing as described previously (2). A series of four standards (20, 40, 60 , and $80 \mathrm{mM} \mathrm{NaCl}$ ) was run before and during perfusate and sample analysis to generate a regression line and assess instrument stability. In analytes suspected to have low chloride concentrations, a midcurve standard was added to the sample or perfusate before titration.

Calculations. The perfusion rate $(\dot{v})$ was calculated as the product of the collected rate $(\dot{v})$ and the $\mathrm{TF} / \mathrm{P}_{\text {in }}$ (ratio of inulin concentration in collected tubular fluid and perfusate). $\mathrm{J}_{\mathrm{tCO} 2}$ was calculated as:

$\mathrm{J}_{\mathrm{tCO} 2}=\left[\left(\dot{v} \times c_{p}\right)-\left(\dot{v} \times c_{c}\right)\right] / L ;$

where $\mathrm{c}_{p}$ and $\mathrm{c}_{c}$ are the measured $\mathrm{tCO}_{2}$ concentrations in perfusate and collected fluid, respectively, and $L$ is the tubule length in millimeters, measured by dissection after latex injection. Chloride fluxes $\left(\mathrm{J}_{\mathrm{Cl}}\right)$ were calculated in the same manner.

Statistics. All data are expressed as the arithmetic mean \pm SEM. Balance, blood, and urine data for groups 1-4 are summarized in Table II. The values represent pooled data from all experiments using group 1 rats, group 2 rats, etc. Statistical significance was assessed, as appropriate, by $t$ testing or one-way ANOVA, followed by Dunnett's test for comparisons versus a control. Tests yielding a $P$ value of $<0.05$ indicated a statistically significant difference between groups.

\section{Results}

\section{Balance, blood, and urine data}

Table II summarizes the balance, blood, and urine data pooled for all experimental animals in groups 1-4. All normally fed animals gained weight, although rats fed the zero- $\mathrm{NaCl}$ diet gained significantly less weight than their counterparts on rat chow $(10 \pm 1$ vs. $15 \pm 1$ grams, $P<0.05)$. Conversely, overnight weight loss was demonstrated in all fasted animals, though the weight loss was attenuated in those animals maintained on a high- $\mathrm{NaCl}$ diet before overnight fasting $(-12 \pm 1$ vs. $-25 \pm 1$ grams, $P<0.05)$. As has been demonstrated previously in this laboratory (1), a significantly lower plasma bicarbonate con-

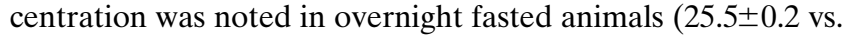
$30.8 \pm 0.2 \mathrm{mM}, P<0.05)$. As expected, there were marked differences in urinary excretion rates of $\mathrm{Na}, \mathrm{K}$, and $\mathrm{Cl}$ among the four groups of rats: group 2 rats (FED/NO SALT) excreted minimal $\mathrm{Na}, \mathrm{K}$, and $\mathrm{Cl}$, compared with the chow-fed controls (group 1) (44 \pm 10 vs. $1,634 \pm 98,507 \pm 35$ vs. $3,771 \pm 174$, and $82 \pm 13$ vs. $2,266 \pm 107 \mu \mathrm{eq} / 16 \mathrm{~h}$, for $\mathrm{Na}, \mathrm{K}$, and $\mathrm{Cl}$ excretion, respectively, $P<0.05$ for each excretion rate versus control), whereas salt loading before overnight fasting (group 4) greatly enhanced $\mathrm{Na}$ and $\mathrm{Cl}$ excretion $(5,237 \pm 810$ vs. $650 \pm 58$ and $4,619 \pm 826$ vs. $495 \pm 54 \mu \mathrm{eq} / 16 \mathrm{~h}$, for $\mathrm{Na}$ and $\mathrm{Cl}$ excretion, respectively, $P<0.05$ for each excretion rate versus control), and decreased urinary $\mathrm{K}$ excretion $(504 \pm 75$ vs. $1,568 \pm 191$ meq/16 h, $P<0.05)$, compared with normally fasted rats 


\begin{tabular}{|c|c|c|c|c|}
\hline & 1. FED & 2. FED/NO SALT & 3. FASTED & 4. FASTED + SALT \\
\hline \multicolumn{5}{|l|}{ Balance } \\
\hline Body weight (grams) & (26) $314 \pm 2$ & (11) $308 \pm 4$ & (16) $289 \pm 2 *$ & (11) $295 \pm 5$ \\
\hline$\Delta$ Body weight overnight (grams) & (26) $15 \pm 1$ & (11) $10 \pm 1 *$ & $(16)-25 \pm 1 *$ & $(11)-12 \pm 1^{\ddagger}$ \\
\hline Food eaten (grams) & (26) $26 \pm 1$ & (11) $22 \pm 1$ & - & - \\
\hline Drink consumed $(\mathrm{ml})$ & (26) $38 \pm 1$ & (11) $44 \pm 5$ & (16) $40 \pm 4$ & (11) $33 \pm 5$ \\
\hline Urine output (ml) & (23) $12 \pm 1$ & (11) $28 \pm 3 *$ & (16) $35 \pm 3 *$ & (9) $27 \pm 5$ \\
\hline \multicolumn{5}{|l|}{ Blood } \\
\hline PRA (ng/ml•h) & (11) $18.4 \pm 1.4$ & (11) $41.6 \pm 0.8^{*}$ & (11) $21.9 \pm 1.8$ & (6) $18.2 \pm 1.9$ \\
\hline $\mathrm{pH}$ & (26) $7.43 \pm 0.01$ & (11) $7.42 \pm 0.01$ & (16) $7.40 \pm 0.01$ & (11) $7.39 \pm 0.01$ \\
\hline $\mathrm{pCO}_{2}(\mathrm{mmHg})$ & (26) $47.9 \pm 0.5$ & (11) $47.2 \pm 1.8$ & (16) $42.4 \pm 0.7^{*}$ & (11) $45.6 \pm 1.2$ \\
\hline$\left[\mathrm{HCO}_{3}\right](\mathrm{mM})$ & (26) $30.8 \pm 0.2$ & (11) $29.7 \pm 0.6$ & (16) $25.5 \pm 0.2 *$ & (11) $26.7 \pm 0.5$ \\
\hline Plasma $[\mathrm{Na}](\mathrm{mM})$ & (26) $145 \pm 0$ & (11) $144 \pm 1$ & (16) $146 \pm 0$ & (10) $158 \pm 4^{\ddagger}$ \\
\hline Plasma $[\mathrm{K}](\mathrm{mM})$ & (26) $4.6 \pm 0.1$ & (11) $4.2 \pm 0.1$ & (16) $4.0 \pm 0.1 *$ & (10) $4.1 \pm 0.1$ \\
\hline Plasma $[\mathrm{Cl}](\mathrm{mM})$ & (26) $102 \pm 1$ & (11) $104 \pm 1$ & (16) $107 \pm 1 *$ & (11) $104 \pm 0$ \\
\hline Hematocrit (\%) & (26) $43.5 \pm 0.5$ & (10) $45.3 \pm 0.7$ & (15) $46.2 \pm 0.5^{*}$ & (10) $43.7 \pm 0.4$ \\
\hline Plasma [protein] (grams/dl) & (26) $5.5 \pm 0.1$ & (10) $6.8 \pm 0.2 *$ & (15) $5.6 \pm 0.1$ & (10) $5.7 \pm 0.1$ \\
\hline \multicolumn{5}{|l|}{ Urine } \\
\hline $\mathrm{pH}$ & (23) $6.81 \pm 0.04$ & (7) $5.93 \pm 0.10 *$ & (16) $6.84 \pm 0.05$ & (8) $6.55 \pm 0.08^{\ddagger}$ \\
\hline $\mathrm{HCO}_{3}$ excretion $(\mu \mathrm{eq} / 16 \mathrm{~h})$ & (23) $201 \pm 31$ & (7) $15 \pm 3^{*}$ & (16) $134 \pm 25$ & (7) $122 \pm 25$ \\
\hline Na excretion $(\mu \mathrm{eq} / 16 \mathrm{~h})$ & (22) $1634 \pm 98$ & (11) $44 \pm 10 *$ & (16) $650 \pm 58$ & (9) $5237 \pm 810^{\ddagger}$ \\
\hline K excretion $(\mu \mathrm{eq} / 16 \mathrm{~h})$ & (22) $3771 \pm 174$ & (11) $507 \pm 35^{*}$ & (16) $1568 \pm 191 *$ & (9) $504 \pm 75^{\ddagger}$ \\
\hline $\mathrm{Cl}$ excretion $(\mu \mathrm{eq} / 16 \mathrm{~h})$ & (22) $2266 \pm 107$ & (10) $82 \pm 13 *$ & (16) $495 \pm 54 *$ & (9) $4619 \pm 826^{\ddagger}$ \\
\hline
\end{tabular}

Values are arithmetic means \pm SEM of pooled data for each group $(n) .{ }^{*} P<0.05$ vs. FED, ${ }^{\ddagger} P<0.05$ vs. FASTED (by one-way ANOVA).

(group 3). PRA was measured in group 1-4 rats (Table II). Predictably, salt-deprived rats (group 2) showed a $100 \%$ increase in PRA compared with normally fed animals $(41.6 \pm 0.8$ vs. $18.4 \pm 1.4 \mathrm{ng} / \mathrm{ml} \cdot \mathrm{h}, P<0.05)$. However, overnight fasting was not associated with a significant change in PRA, and this was not modified by salt loading $(18.2 \pm 1.9$ vs. $21.9 \pm 1.8 \mathrm{ng} /$ $\mathrm{ml} \cdot \mathrm{h}, P=\mathrm{NS})$.

\section{Microperfusion results}

Blood pressure was monitored continuously throughout the surgical and experimental periods (average mean blood pressure for all experimental animals was $134 \pm 2 \mathrm{mmHg}$ ). Similarly, the tubular transit time was repeated as a measure of kidney function. There were no changes noted in blood pressure or transit time after the enalaprilat and losartan infusions. As noted, samples were taken within 20-60 min of these infusions, making changes in aldosterone effects unlikely (see Discussion).
Effect of dietary salt manipulation. Table III summarizes the results of microperfusion experiments to assess the effects of dietary salt deprivation, and dietary salt loading before overnight fasting, on LD water, chloride, and bicarbonate fluxes. Water reabsorption $\left(\mathrm{J}_{\mathrm{v}}\right)$ increased significantly after overnight fasting $(2.9 \pm 0.2$ vs. $1.6 \pm 0.3 \mathrm{nl} / \mathrm{min} \cdot \mathrm{mm}, P<0.05)$. This effect was mitigated somewhat by dietary salt loading $(2.3 \pm 0.4$ vs. $2.9 \pm 0.2 \mathrm{nl} / \mathrm{min} \cdot \mathrm{mm}, P<0.1)$. There was no statistically significant difference in LD chloride flux among the four groups studied, although variations in $\mathrm{J}_{\mathrm{tCO} 2}$ were observable with the different treatments. As has been demonstrated previously by this laboratory in the entire distal tubule, overnight fasting stimulated enhanced LD bicarbonate reabsorption, compared with normal feeding $(50 \pm 4$ vs. $16 \pm 6 \mathrm{pmol} /$ $\mathrm{min} \cdot \mathrm{mm}, P<0.05)$. Rats fed a zero- $\mathrm{NaCl}$ diet for $3 \mathrm{~d}$ (group 2) also reabsorbed bicarbonate briskly, in fact, to a level not significantly different from overnight-fasted rats $(45 \pm 5$ vs. $50 \pm 4$ $\mathrm{pmol} / \mathrm{min} \cdot \mathrm{mm}, P=\mathrm{NS})$. When rats were salt loaded before overnight fasting (group 4), in an attempt to suppress the fast-

Table III. Summary of Microperfusion Data: Effect of Dietary Salt Manipulation

\begin{tabular}{|c|c|c|c|c|c|c|c|c|c|}
\hline & Tubule length & Perfusion rate & Perfused $\mathrm{Cl}$ & Collected $\mathrm{Cl}$ & Perfused $\mathrm{tCO}_{2}$ & Collected $\mathrm{tCO}_{2}$ & $\mathrm{~J}_{\mathrm{v}}$ & $\mathrm{J}_{\mathrm{Cl}}$ & $\mathrm{J}_{\mathrm{tCO} 2}$ \\
\hline & $m m$ & nl/min & $m M$ & $m M$ & $m M$ & $m M$ & $\mathrm{nl} / \mathrm{min} \cdot \mathrm{mm}$ & \multicolumn{2}{|c|}{$\mathrm{pmol} / \mathrm{min} \cdot \mathrm{mm}$} \\
\hline 1. FED $(7 / 7)$ & $1.6 \pm 0.1$ & $7.7 \pm 0.2$ & $23.6 \pm 0.3$ & $47.5 \pm 5.2$ & $28.2 \pm 0.2$ & $36.7 \pm 1.4$ & $1.6 \pm 0.3$ & $-55 \pm 31$ & $16 \pm 6$ \\
\hline 2. FED/NO SALT(7/6) & $1.6 \pm 0.1$ & $7.5 \pm 0.2$ & $23.8 \pm 0.2$ & $48.4 \pm 4.4$ & $28.6 \pm 0.6$ & $34.4 \pm 1.4$ & $2.1 \pm 0.2$ & $-15 \pm 14$ & $45 \pm 5^{*}$ \\
\hline 3. FASTED (8/6) & $1.4 \pm 0.1$ & $7.8 \pm 0.2$ & $24.8 \pm 0.2 *$ & $42.3 \pm 5.7$ & $28.7 \pm 0.4$ & $40.2 \pm 2.2$ & $2.9 \pm 0.2 *$ & $16 \pm 24$ & $50 \pm 4 *$ \\
\hline 4. FASTED+SALT $(5 / 5)$ & $1.6 \pm 0.2$ & $7.9 \pm 0.3$ & $24.8 \pm 0.3$ & $51.8 \pm 7.3$ & $28.7 \pm 0.7$ & $37.2 \pm 2.1$ & $2.3 \pm 0.4$ & $-18 \pm 10$ & $38 \pm 3^{\ddagger}$ \\
\hline
\end{tabular}

Values are arithmetic means \pm SEM; (No. tubules/No. rats); ${ }^{*} P<0.05$ vs. FED (by one-way ANOVA), ${ }^{\ddagger} P<0.05$ vs. FASTED (by $t$ test). 
Table IV. Summary of Microperfusion Data: Effect of Inhibitors of AII

\begin{tabular}{|c|c|c|c|c|c|c|c|c|c|}
\hline & Tubule length & Perfusion rate & Perfused Cl & Collected Cl & Perfused $\mathrm{tCO}_{2}$ & Collected $\mathrm{tCO}_{2}$ & $\mathrm{~J}_{\mathrm{v}}$ & $\mathrm{J}_{\mathrm{Cl}}$ & $\mathrm{J}_{\mathrm{tCO} 2}$ \\
\hline & $m M$ & $\mathrm{nl} / \mathrm{min}$ & $m M$ & $m M$ & $m M$ & $m M$ & $\mathrm{nl} / \mathrm{min} \cdot \mathrm{mm}$ & \multicolumn{2}{|c|}{$\mathrm{pmol} / \mathrm{min} \cdot \mathrm{mm}$} \\
\hline 2. FED/NO SALT (7/6) & $1.6 \pm 0.1$ & $7.5 \pm 0.2$ & $23.8 \pm 0.2$ & $48.4 \pm 4.4$ & $28.6 \pm 0.6$ & $34.4 \pm 1.4$ & $2.1 \pm 0.2$ & $-15 \pm 14$ & $45 \pm 5$ \\
\hline (b) + enalaprilat $(7 / 5)$ & $1.7 \pm 0.1$ & $8.1 \pm 0.3$ & $25.4 \pm 0.3 *$ & $35.1 \pm 3.6^{*}$ & $29.7 \pm 0.2$ & $39.8 \pm 2.3$ & $1.6 \pm 0.2$ & $6 \pm 19$ & $20 \pm 5^{*}$ \\
\hline 3. FASTED $(8 / 6)$ & $1.4 \pm 0.1$ & $7.8 \pm 0.2$ & $24.8 \pm 0.2$ & $42.3 \pm 5.7$ & $28.7 \pm 0.4$ & $40.2 \pm 2.2$ & $2.9 \pm 0.2$ & $16 \pm 24$ & $50 \pm 4$ \\
\hline (b) + enalaprilat $(7 / 5)$ & $1.7 \pm 0.1$ & $7.8 \pm 0.3$ & $25.3 \pm 0.1$ & $46.5 \pm 3.6$ & $29.7 \pm 0.5$ & $38.9 \pm 2.5$ & $1.6 \pm 0.2^{\ddagger}$ & $-15 \pm 10$ & $24 \pm 2^{\ddagger}$ \\
\hline (c) + losartan $(6 / 5)$ & $1.6 \pm 0.1$ & $7.9 \pm 0.3$ & $25.0 \pm 0.2$ & $52.7 \pm 5.8$ & $29.0 \pm 0.2$ & $38.6 \pm 2.3$ & $1.6 \pm 0.2^{\ddagger}$ & $-55 \pm 28$ & $16 \pm 4^{\ddagger}$ \\
\hline
\end{tabular}

Values are arithmetic means \pm SEM; (No. tubules/No. rats); $* P<0.05$ vs. FED/NO SALT (by $t$ test), ${ }^{*} P<0.05$ vs. FASTED (by one-way ANOVA).

ing-stimulated increase in $\mathrm{LD} \mathrm{J}_{\mathrm{tCO} 2}$, a small but significant decrease in $\mathrm{J}_{\mathrm{tCO} 2}$ was demonstrated ( $38 \pm 3$ vs. $50 \pm 4 \mathrm{pmol} /$ $\mathrm{min} \cdot \mathrm{mm}, P<0.05)$. Therefore, these results suggest that LD $\mathrm{J}_{\mathrm{tCO} 2}$ is modulated by factors which are regulated by salt intake, such as AII. Therefore, the two animal preparations in which there was enhanced LD $\mathrm{J}_{\mathrm{tCO} 2}$ (groups 2 and 3) were used in further experiments, targeting the effect of AII and its inhibitors.

Effect of inhibitors of AII. Table IV summarizes the results of experiments undertaken with inhibitors of AII: enalaprilat (an ACE inhibitor) and losartan (a specific inhibitor of the $\mathrm{AT}_{1}$ receptor). Group 2 rats were infused with enalaprilat before micropuncture, and in these rats $\mathrm{LD} \mathrm{J}_{\mathrm{tCO} 2}$ was reduced by $60 \%(20 \pm 5 \mathrm{vs} .45 \pm 5 \mathrm{pmol} / \mathrm{min} \cdot \mathrm{mm}, P<0.05)$ to a level not different from normally fed group 1 rats $(20 \pm 5 \mathrm{vs}$. $16 \pm 6 \mathrm{pmol} /$ $\mathrm{min} \cdot \mathrm{mm}, P=\mathrm{NS})$. $\mathrm{J}_{\mathrm{v}}$ also tended to decrease with the enalaprilat infusion $(1.6 \pm 0.2 \mathrm{vs} .2 .1 \pm 0.2 \mathrm{nl} / \mathrm{min} \cdot \mathrm{mm})$, but not to a statistically significant level. In group 3 rats, both enalaprilat and losartan were systemically infused before micropuncture, and each produced a significant decrease in $\operatorname{LD~J}_{\mathrm{tCO} 2}(50 \pm 4,24 \pm 2$, and $16 \pm 4 \mathrm{pmol} / \mathrm{min} \cdot \mathrm{mm}$ for FASTED, FASTED + enalaprilat, and FASTED + losartan, respectively, $P<0.05$ for each inhibitor versus control). In these overnight fasted animals, $\mathrm{J}_{\mathrm{v}}$ was also significantly decreased by these inhibitors $(2.9 \pm 0.2$, $1.6 \pm 0.2$, and $1.6 \pm 0.2 \mathrm{nl} / \mathrm{min} \cdot \mathrm{mm}$, for FASTED, FASTED + enalaprilat, and FASTED + losartan, respectively, $P<0.05$ for each inhibitor versus control).

Effect of luminal AII perfusion. Table V summarizes the results obtained by luminal perfusion of $10^{-11} \mathrm{M}$ AII in fed rats (group 1). A modified perfusate (1a, see Table I) was designed for luminal AII experiments, which included $1.8 \mathrm{mM}$ calcium and $0.1 \%$ albumin (added to prevent adherence of the peptide to the surface of glassware). Therefore, an additional group of control rats was perfused with the calcium/albumin-containing vehicle: there was no difference in $\mathrm{J}_{\mathrm{v}}, \mathrm{J}_{\mathrm{Cl}}$, or $\mathrm{J}_{\mathrm{tCO} 2}$ (Table $\mathrm{V}$ ) in these animals compared with controls perfused with the original solution.

The addition of $10^{-11} \mathrm{M}$ AII stimulated brisk LD $\mathrm{J}_{\mathrm{tCO} 2}$ ( $45 \pm 6$ vs. $18 \pm 4 \mathrm{pmol} / \mathrm{min} \cdot \mathrm{mm}, P<0.05$ ) which was not associated with an increase in $\mathrm{J}_{\mathrm{v}}(1.7 \pm 0.1 \mathrm{vs} .1 .8 \pm 0.3 \mathrm{nl} / \mathrm{min} \cdot \mathrm{mm}, P=$ NS). Simultaneous perfusion of $10^{-6} \mathrm{M}$ losartan and $10^{-11} \mathrm{M}$ AII completely abolished this increase ( $21 \pm 4$ vs. $18 \pm 4 \mathrm{pmol} /$ $\min \cdot \mathrm{mm}, P=\mathrm{NS}$ ), and again there was no effect on $\mathrm{J}_{\mathrm{v}}$ $(1.7 \pm 0.2$ vs. $1.8 \pm 0.3 \mathrm{nl} / \mathrm{min} \cdot \mathrm{mm}, P=\mathrm{NS})$.

\section{Discussion}

The present in vivo microperfusion data support the view that AII enhances LD bicarbonate reabsorption after overnight fasting or ingestion of a zero-salt diet, and that these effects can be diminished, or completely abrogated, by enalaprilat or losartan. Further, with respect to luminal transport, we demonstrate that in vivo luminal perfusion of AII at a physiologic concentration also briskly augments $\mathrm{LD} \mathrm{J}_{\mathrm{tCO} 2}$. Simultaneous perfusion with the specific $\mathrm{AT}_{1}$ inhibitor losartan abolishes this response.

The experimental preparation. We recognize that interpretation of acute studies involving AII in anesthetized rats should be made with caution. PRA and plasma AII and aldosterone levels may each be influenced by anesthesia per se, and variably in our different experimental groups. Because PRA was unchanged in fasted rats, the ability of losartan to reduce $\mathrm{LD} \mathrm{J}_{\mathrm{tCO} 2}$ by two-thirds in these animals suggests that local renal tissue AII mediates the response, rather than plasmaderived AII.

Table V. Summary of Microperfusion Data: Effect of Luminal AII Perfusion

\begin{tabular}{|c|c|c|c|c|c|c|c|c|c|}
\hline & Tubule length & Perfusion rate & Perfused $\mathrm{Cl}$ & Collected $\mathrm{Cl}$ & Perfused $\mathrm{tCO}_{2}$ & Collected $\mathrm{tCO}_{2}$ & $\mathrm{~J}_{\mathrm{v}}$ & $\mathrm{J}_{\mathrm{Cl}}$ & $\mathrm{J}_{\mathrm{tCO} 2}$ \\
\hline & $m M$ & $\mathrm{nl} / \mathrm{min}$ & $m M$ & $m M$ & $m M$ & $m M$ & $\mathrm{nl} / \mathrm{min} \cdot \mathrm{mm}$ & \multicolumn{2}{|c|}{$\mathrm{pmol} / \mathrm{min} \cdot \mathrm{mm}$} \\
\hline 1. FED* $(9 / 7)$ & $1.6 \pm 0.2$ & $8.2 \pm 0.3$ & $25.5 \pm 0.8$ & $44.2 \pm 3.9$ & $27.7 \pm 0.3$ & $37.6 \pm 1.8$ & $1.8 \pm 0.3$ & $-14 \pm 13$ & $18 \pm 4$ \\
\hline (b) $+10^{-11} \mathrm{M}$ AII (8/5) & $1.5 \pm 0.1$ & $8.1 \pm 0.3$ & $26.5 \pm 0.4$ & $41.9 \pm 4.7$ & $29.1 \pm 0.4^{\ddagger}$ & $30.8 \pm 1.3^{\ddagger}$ & $1.7 \pm 0.1$ & $-18 \pm 16$ & $45 \pm 6^{\ddagger}$ \\
\hline (c) $+10^{-11} \mathrm{M} \mathrm{AII} /$ & & & & & & & & & \\
\hline$+10^{-6} \mathrm{M}$ losartan $(8 / 7)$ & $1.6 \pm 0.1$ & $7.9 \pm 0.2$ & $26.9 \pm 0.2$ & $46.3 \pm 2.9$ & $27.6 \pm 0.6$ & $36.3 \pm 2.5$ & $1.7 \pm 0.2$ & $-17 \pm 11$ & $21 \pm 4$ \\
\hline
\end{tabular}

*FED rats perfused with perfusion solution 1a containing $1.8 \mathrm{mM}$ calcium and $0.1 \%$ albumin; values are arithmetic means \pm SEM; (No. tubules/No. rats); ${ }^{\ddagger} P<0.05$ vs. FED (by one-way ANOVA). 
There is also the possibility that plasma aldosterone levels varied in the different protocols and directly stimulated bicarbonate retrieval in fasted and salt-deprived rats. However, we think it unlikely that, within $20-60 \mathrm{~min}$ of the infusion of blocking doses of enalaprilat or losartan, an enhanced late distal tubule mineralocorticoid-driven bicarbonate reabsorptive flux could be abruptly returned to normal levels, as was observed. Indeed, Tofovic et al. (5) report that infusion of losartan in anesthetized rats, at twice the dose we used, and over the same time period, does not affect blood pressure or plasma aldosterone concentration. Further, we show that $10^{-11} \mathrm{M}$ intraluminal AII perfusion, acting via the $\mathrm{AT}_{1}$ receptor, quantitatively simulates responses elicited by zero-salt diet consumption and fasting: control values of $\sim 20 \mathrm{pmol} / \mathrm{min} \cdot \mathrm{mm}$ rise more than twofold and return to the same value with enalaprilat and losartan. In any case, such aldosterone effects would not be inconsistent with our conclusion that AII is the mediator of change. Clearly, they would be a consequence of changes in AII levels on adrenal zona glomerulosa cells. Quantitation of these possible secondary effects of aldosterone would require, of course, repetition of all experimental protocols in adrenalectomized rats, concomitant with measurement of renal tissue AII levels.

What is the origin of AII which causes the stimulatory effects of zero-salt diet or fasting on $\mathrm{LD} \mathrm{J}_{\mathrm{tCO}}$ ? One possibility is that circulating levels of AII increase with salt deprivation or with fasting, and that AII is filtered at the glomerulus and delivered to distal nephron sites. However, we did not observe an increase in PRA in fasted animals, rendering this possibility less likely. Furthermore, proximal tubule brush border peptidase activity (6) might not permit sufficient delivery of intact AII to distal sites.

An alternate hypothesis regarding the origin of AII is that its proximal tubule synthesis is enhanced by a zero-salt diet and by fasting. As demonstrated by Seikaly et al. (7) and by Navar et al. (8), luminal concentrations of AII in proximal tubule are in the nanomolar range. These high tubular fluid concentrations likely reflect secretion of AII from proximal tubule cells, since these cells contain all the components of an intrarenal renin-angiotensin system. Vos and colleagues (9) have demonstrated that, in humans, urinary AII is derived from intrarenal synthesis, presumably from proximal tubule origin. Therefore, it is conceivable that proximal tubule synthesis of AII in the rat is enhanced with a zero-salt diet or with fasting. Depending on the site of production of this AII within the proximal tubule, it may bypass some or much of the brush border peptidase activity, allowing delivery to $\mathrm{AT}_{1}$ receptor sites on the luminal surface of the LD tubule. Along these lines, a recent study by Cheng et al. (10) demonstrated that AII upregulates $\mathrm{AT}_{1}$ receptors in rabbit proximal tubule and that lowsalt diets were associated with increased proximal tubule $\mathrm{AT}_{1}$ receptors, suggesting the possibility of enhanced local AII synthesis.

Localization of LD AII receptors. The mRNA which encodes $\mathrm{AT}_{1}$ receptors has been localized to collecting ducts of rat (11), and specific binding of AII has been demonstrated in distal nephron segments (12). In rabbit outer cortical collecting duct, a segment rich in B type intercalated cells, a preliminary report by Weiner et al. (13) demonstrated that high concentrations of AII $\left(10^{-7} \mathrm{M}\right)$ stimulated bicarbonate secretion, via binding to basolateral $\mathrm{AT}_{1}$ receptors. In microdissected rat cortical collecting ducts, Tojo et al. (14) have shown recently that AII $\left(10^{-10}-10^{-5} \mathrm{M}\right)$ caused concentration-dependent inhibition of $\mathrm{H}^{+}$-ATPase activity, with maximal inhibition at $10^{-8}$ $\mathrm{M}$, via binding to $\mathrm{AT}_{1}$ receptors. These investigators did not determine receptor localization and did not distinguish between possible effects of AII on the basolateral $\mathrm{H}^{+}$-ATPase activity of B type intercalated cells and the apical $\mathrm{H}^{+}$-ATPase of A type intercalated cells.

Notwithstanding the foregoing, our direct in vivo measurements, demonstrating that low concentrations of AII at the luminal surface of the late distal tubule briskly enhance $\mathrm{J}_{\mathrm{tCO} 2}$ (an effect abolished by simultaneous losartan perfusion), indicate that there must be luminal receptors of the $\mathrm{AT}_{1}$ subtype. Of course, it is possible that both luminal and basolateral $\mathrm{AT}_{1}$ receptors coexist.

Possible signaling pathways and transporters mediating the stimulatory effects of AII. In the proximal tubule, as shown by the elegant studies of Cogan and his colleagues $(15,16)$, high concentrations of luminal or basolateral AII $\left(>10^{-8} \mathrm{M}\right)$ inhibit apical $\mathrm{Na}^{+}-\mathrm{H}^{+}$exchange, while lower concentrations stimulate this antiporter. Therefore, it is also possible that AII may modulate a distal tubule $\mathrm{Na}^{+}-\mathrm{H}^{+}$exchanger, should it exist. In preliminary reports, Wang et al. $(17,18)$ observed that the early, but not late, distal tubule has apical $\mathrm{Na}^{+}-\mathrm{H}^{+}$exchange activity which is stimulated by AII. However, these results are somewhat at variance with the studies of Fernandez et al. (19), showing that the LD tubule also possesses an apical $\mathrm{Na}^{+}-\mathrm{H}^{+}$antiporter. Of course, our results do not elucidate the specific transporters or signaling pathways whereby AII stimulates $\mathrm{LD} \mathrm{J}_{\mathrm{tCO} 2}$.

Is it possible that a decrease in unidirectional bicarbonate secretion is elicited by increased levels of systemic or luminal AII? As Tojo et al. have noted (14), the rat cortical collecting duct contains predominantly B type intercalated cells. There is strong evidence that accumulation of cAMP in B type intercalated cells stimulates bicarbonate secretion (20-22). Accordingly, insofar as AII is associated with decreased proximal tubule adenylate cyclase activity (23), it is conceivable that this second messenger could play a role at the distal tubule site modulating bicarbonate transport. Two observations bear critically on this possibility. Recently, we have shown in fasted rats (2) that isoproterenol-known to increase cAMP $(21,22)$ decreases bicarbonate reabsorption. Since our present studies demonstrate that AII increases bicarbonate reabsorption, it is possible, therefore, that isoproterenol raised intracellular levels of cAMP, which had been reduced by AII in fasted rats, thereby stimulating B type intercalated cell bicarbonate secretion. Also relevant is our recent demonstration (24) that AII suppresses cAMP in cultured rabbit collecting duct cells. This proposal, that AII may act to increase late distal bicarbonate reabsorption via modulation of intracellular cAMP, is worthy of future study, perhaps by the addition of 8-bromo-cAMP to the perfusate.

What is the significance of enhanced $L D J_{t C O 2}$ in fasted rats? In 1849, Henry Bence Jones noted, "The degree of acidity of the urine was found to be greatest a short time before food was taken ..." (25). We have reported already that fasting a rat-withholding food overnight-before experimentation produces a fall in urine $\mathrm{pH}$ and a $5 \mathrm{mM}$ fall in plasma $\left[\mathrm{HCO}_{3}\right]$ when compared with the normally fed rat (1). Whatever the causes of these acid-base effects, the enhanced capacity for distal tubules to retrieve bicarbonate would tend to restore plasma bicarbonate concentration to normal. This may 
be analogous to the enhanced $\mathrm{J}_{\mathrm{tCO} 2}$ after acid gavage (26), and the persistent alkalemia induced by selective chloride depletion, accompanied, invariably, by some degree of extracellular fluid volume contraction. These and other observations raise the possibility that AII contributes to acid-base homeostasis.

In summary, we have shown that in fasted rats and in rats fed a zero-salt diet LD $\mathrm{J}_{\mathrm{tCO} 2}$ is markedly enhanced, and that this effect is abrogated by blockade of $\mathrm{AT}_{1}$ receptors or inhibition of AII synthesis. In addition, a physiologic concentration of luminal AII stimulated $\mathrm{J}_{\mathrm{tCO} 2}$ in the LD tubule. Our results support the hypothesis that AII acts as an endocrine or paracrine hormone to modulate $\mathrm{LD}_{\mathrm{t}_{\mathrm{CO} 2}}$ and therefore may be an important in vivo regulator of systemic acid-base balance.

\section{Acknowledgments}

What is good in this work we dedicate to the memory of Marty Cogan: brilliant investigator, nurturing teacher, and steadfast friend.

Enalaprilat was kindly supplied by Dr. Ernest Prégent of Merck Frosst Canada Inc., Pointe-Claire, Quebec, Canada, while losartan was a generous donation from Dr. Ronald Smith of The DuPont Merck Pharmaceutical Company, Wilmington, DE.

This work was supported by a grant from The Medical Research Council of Canada.

\section{References}

1. Levine, D. Z., M. Iacovitti, L. Nash, and D. Vandorpe. 1988. Secretion of bicarbonate by rat distal tubules in vivo. Modulation by overnight fasting. $J$. Clin. Invest. 81:1873-1878.

2. Levine, D. Z., M. Iacovitti, S. Buckman, and V. Harrison. 1994. In vivo modulation of rat distal tubule net $\mathrm{HCO}_{3}$ flux by VIP, isoproterenol, angiotensin II, and ADH. Am. J. Physiol. 266 (Renal Fluid Electrolyte Physiol. 35): F878-F883.

3. Nocenti, M. R., S. Simchon, and L. J. Cizek. 1975. Analysis of the reninangiotensin system during fasting in adult male rabbits. Proc. Soc. Exp. Biol. Med. 150:142-147.

4. Levine, D. Z. 1990. Single-nephron studies: implications for acid-base regulation. Kidney Int. 38:744-761.

5. Tofovic, S. P., A. S. Pong, and E. K. Jackson. 1991. Effects of angiotensin subtype 1 and subtype 2 receptor antagonists in normotensive versus hypertensive rats. Hypertension (Dallas). 18:774-782.

6. Peterson, D. R., G. Chrabaszcz, W. R. Peterson, and S. Oparil. 1979. Mechanism for renal tubular handling of angiotensin. Am. J. Physiol. 236 (Renal Fluid Electrolyte Physiol. 5):F365-F372.

7. Seikaly, M. G., B. S. Arant, Jr., and F. D. Seney, Jr. 1990. Endogenous angiotensin concentrations in specific intrarenal fluid compartments of the rat.
J. Clin. Invest. 86:1352-1357.

8. Navar, L. G., L. Lewis, H. Hymel, B. Braam, and K. D. Mitchell. 1994. Tubular fluid concentrations and kidney contents of angiotensins I and II in anesthetized rats. J. Am. Soc. Nephrol. 5:1153-1158.

9. Vos, P. F., P. Boer, B. Braam, and H. A. Koomans. 1994. The origin of urinary angiotensins in humans. J. Am. Soc. Nephrol. 5:215-223.

10. Cheng, H.-F., B. N. Becker, K. D. Burns, and R. C. Harris. 1995. Angiotensin II upregulates type I angiotensin II receptors in renal proximal tubule. $J$. Clin. Invest. 95:2012-2019.

11. Terada, Y., K. Tomita, H. Nonoguchi, and F. Marumo. 1993. PCR localization of angiotensin II receptor and angiotensinogen mRNAs in rat kidney. Kidney Int. 43:1251-1259.

12. Mujais, S. K., S. Kauffman, and A. I. Katz. 1986. Angiotensin II binding sites in individual segments of the rat nephron. J. Clin. Invest. 77:315-318.

13. Weiner, I. D., A. Riggs, K. M. Madsen, A. Tojo, and C. C. Tisher. 1993. Angiotensin II (AII) stimulates $\mathrm{HCO}_{3}^{-}$secretion in the rabbit cortical collecting duct (CCD). J. Am. Soc. Nephrol. 4:850a. (Abstr.)

14. Tojo, A., C. C. Tisher, and K. M. Madsen. 1994. Angiotensin II regulates $\mathrm{H}^{+}$-ATPase activity in rat cortical collecting duct. Am. J. Physiol. 267 (Renal Fluid Electrolyte Physiol. 36):F1045-F1051.

15. Liu, F.-Y., and M. G. Cogan. 1987. Angiotensin II: a potent regulator of acidification in the rat early proximal convoluted tubule. J. Clin. Invest. 80:272275 .

16. Liu, F.-Y., and M. G. Cogan. 1988. Angiotensin II stimulation of hydrogen ion secretion in the rat early proximal tubule. J. Clin. Invest. 82:601-607.

17. Wang, T., and G. Giebisch. 1994. Angiotensin II regulates bicarbonate and fluid transport in the early and late distal tubule in rat kidney. J. Am. Soc. Nephrol. 5:673a. (Abstr.)

18. Wang, T., and G. Giebisch. 1995. Early and late distal tubule sodium, chloride and bicarbonate transport are regulated by angiotensin II. XIIth Int. Congr. Nephrol. 115a. (Abstr.)

19. Fernandez, R., M. J. Lopes, R. F. De Lira, W. F. G. Dantas, E. J. Cragoe, Jr., and G. Malnic. 1994. Mechanism of acidification along cortical distal tubule of the rat. Am. J. Physiol. 266 (Renal Fluid Electrolyte Physiol. 35):F218F226.

20. Fejes-Toth, G., and A. Naray-Fejes-Toth. 1989. Isolated principal and intercalated cell: hormone responsiveness and $\mathrm{Na}^{+}-\mathrm{K}^{+}$-ATPase activity. Am. J. Physiol. 256 (Renal Fluid Electrolyte Physiol. 25):F742-F750.

21. Schuster, V. L. 1985. Cyclic adenosine monophosphate-stimulated bicarbonate secretion in rabbit cortical collecting tubules. J. Clin. Invest. 75:20562064.

22. Schuster, V. L. 1993. Function and regulation of collecting duct intercalated cells. Annu. Rev. Physiol. 55:267-288.

23. Schelling, J. R., H. Singh, R. Marzec, and S. L. Linas. 1994. Angiotensin II-dependent proximal tubule sodium transport is mediated by cAMP modulation of phospholipase C. Am. J. Physiol. 267 (Cell Physiol. 36):C1239-C1245.

24. Burns, K. D., L. Regnier, A. Roczniak, D. Lajeunesse, and R. L. Hébert. 1994. An immortalized rabbit cortical collecting duct (CCD) cell line with functional angiotensin II (ANG II) receptors. J. Am. Soc. Nephrol. 5:656a. (Abstr.)

25. Bence Jones, H. 1849. Contributions to the chemistry of the urine: on the variations of the acidity of the urine in the state of health. Philos. Trans. $R$. Soc. Lond. 139:235-252.

26. Levine, D. Z. 1985. An in vivo microperfusion study of distal tubule bicarbonate reabsorption in normal and $\mathrm{NH}_{4} \mathrm{Cl}$ rats. J. Clin. Invest. 75:588-595. 